\title{
Effectiveness of the Combination of Solution-Focused Therapy and Narrative Therapy in Marital Adjustment among Incompatible Iranian Women
}

\author{
Azadeh Shirashiani ${ }^{1}$, Ebrahim Namani ${ }^{2 *}$ \\ ${ }^{1}$ MA in Counseling, Department of Psychology, Department of Psychological Sciences, Faculty of Humanities, Neyshabur Branch, \\ Islamic Azad University, Neyshabur, Iran \\ ${ }^{2}$ Assistant Professor of Counseling, Department of Educational Sciences, Hakim Sabzevari University, Sabzevar, Iran \\ Email: *a.namani@hsu.ac.ir
}

How to cite this paper: Shirashiani, A. and Namani, E. (2017) Effectiveness of the Combination of Solution-Focused Therapy and Narrative Therapy in Marital Adjustment among Incompatible Iranian Women. Open Journal of Psychiatry, 7, 79-89. https://doi.org/10.4236/ojpsych.2017.72008

Received: December 12, 2016

Accepted: April 21, 2017

Published: April 24, 2017

Copyright (ङ 2017 by authors and Scientific Research Publishing Inc. This work is licensed under the Creative Commons Attribution International License (CC BY 4.0).

http://creativecommons.org/licenses/by/4.0/

\begin{abstract}
The present study aims to examine the effectiveness of the combination of solution-focused therapy and narrative therapy in marital adjustment of incompatible women. This research is a pretest-posttest quasi-experimental study design with a nonequivalent control group. The statistical population comprises all the incompatible women who referred to the counseling clinics of Neyshabour in May 2016 (1500 admission per month). The research sample consists of 24 incompatible women who were selected through Randomand available sampling method. For data collection, Marital Adjustment Scale by Spinner was applied. The data were analyzed using the analysis of covariance test and with the aid of SPSS-22 software. The findings demonstrated that the combination of solution-focused therapy and narrative therapy is significantly effective in marital adjustment of incompatible women $(P<$ 0.05). Thus, it can be stated that the combination of solution-focused therapy and narrative therapy can help to promote adjustment among incompatible women.
\end{abstract}

\section{Keywords}

Solution-Focused Therapy, Narrative Therapy, Marital Adjustment, Incompatible Women

\section{Introduction}

The cornerstone of the family is marriage. Marriage needs cooperation, empathy, unity, interest, kindness, tolerance and accountability. By starting marriage 
and creating a marital relationship, marital adjustment becomes an important variable in relation to the quality of marriage. Marital adjustment is an objective sense of happiness, satisfaction and pleasure experienced by the man and woman with regard to all aspects of the marital relationship. Marital adjustment is considered as one of the most important components of couples' emotional stability [1]. [2] regards marital adjustment as the compatibility between the current situation and expected situation. According to this definition, marital adjustment exists when the existing situation of the individual in marital relations conforms to his expectations. Marital adjustment is affected by a set of various factors none of which is sufficient by itself for creating satisfaction. However, these factors can be diverse among different couples and cultures and multiple personality, culture, faith, cognitive, communicative, emotional and social factors can influence it [3]. By the same token, symbolic interaction theory describes family as a unit of interaction between personalities and defines marital adjustment in family with regard to the manner of transferring bilateral meanings which take a particular color and form in various cultures [4]. Marital adjustment is widely used in marital and family studies. This term is associated with many other terms such as "marital happiness", "marital satisfaction" and "marital stability". While each of the previous terms shows only one dimension of marriage, marital adjustment is a multi-dimensional term which makes clear the multiple levels of marriage and is a process that is created during the couples' life because its requirements are the adjustment of tastes, recognition of personality traits, creation of behavioral rules and formation of interactional patterns. Hence, marital adjustment is an evolutionary process between husband and wife [5].

Given the importance of the component of marital adjustment in family stability, we intend in this study to raise an approach that leads to the promotion of this component in incompatible women. In the field of applied psychology, various couples' therapy approaches have been developed with the aim of increasing marital adjustment and reducing conflict and confusion in communication between couples, which are also applicable to incompatibility of couples. One of these approaches is the short-term solution-focused approach. Short-term solution-focused therapy is one of the effective treatment approaches to help the individuals who are faced with marital stress. Insoo Kim Berg and Dishizher in the center for short-term family therapy in Milwaukee and Wisconsin invented the short-term solution-focused therapy [6].

According to the theory by [7], this approach tends to give the clients this feeling that they are heard and that they are unique people; the one who has ability and capability of growth for his part [8]. Solution-focused therapy has a non-pathological perspective towards the clients and helps them find a solution for their current problems. In this approach, unlike the problem-focused perspective, the emphasis is on finding solutions instead of problems [9]. Therefore, solution-focused therapy is based on solution-making, not problem-solving and is directed by discovering the current forces of the clients and hopefulness about 
future not discussing the existing issues and their causes in the past [10].

Basically, short-term solution-focused therapy is grounded on the assumption that it should change the clients' perception of their problems and possible solutions. Short-term solution-focused therapy makes such a change through speaking with clients about how to solve their problems [11]. But despite the consistency of solution-focused model with the brevity and scientism of strategic approaches, therapists of this school emphasize the collaboration between the therapist and client in making solution-focused narratives. As a result, solutionfocused therapists can raise the problems of clients by getting help from narratives and provide solutions for those problems. So, helping and training the couples to express the problems leading to marital dissatisfaction and reduced intimacy between husband and wife, forgetting the past mistakes and injuries and laying stress on the role of past inefficient narratives of life events in decreasing the intimate relationships between couples can be considered among the activities that are effective in restoring and enhancing intimacy in relations between spouses [12] [13]. For example, [14] conducted a study and investigated the effectiveness of short-term solution-focused group couples therapy in improving the marital relationship of women. They reported that solution-focused intervention therapy can be used to improve and promote the quality of marital relations.

Indeed, recent studies reveal that the stories of couples about their own relationships indicate each couple's effort to give narrative meaning to their experiences of intimacy with another couple [15]. Today, social psychologists have applied narrative techniques (telling the life story and replacing stories with positive meaning) to test the hypotheses relating to the dynamics of close, intimate and affectionate relationships in relations between spouses in order to improve family functions and promote intimacy [16] [17]. Making stories for important events in relations between couples leads to success in integrating the subject of intimacy within a positive emotional framework and ultimately brings communicative and psychological well-being of couples [18]. In this respect, [19] in an article entitled "Analyzing the narratives of the relationships between couples" came to the conclusion that group narrative therapy is effective in reducing cognitive vulnerability and substituting adaptive management solutions to deal with marital problems.

Hence, it can be mentioned that narrative therapy is a process to help the individuals overcome their problems through engaging in therapeutic conversations. This process includes speaking, listening, retelling the stories and listening to the stories again. This approach views the individuals as the main specialists of their life and regards problems as the separate sections from people and believes that individuals possess many skills, beliefs, values and abilities that help them in reducing the effects of problems on their lives and provide a way of understanding the human experience [20]. Consequently, we can help people in understanding their problems by resorting to these narratives and assist them to solve their problems through the solution-focused approach. Based on the fore- 
going, it can be said that these two approaches can be practically placed alongside each other and we can benefit from their combination to solve the problems of marital maladjustment. Thus, the present research seeks to answer the question as to whether the combination of solution-focused therapy and narrative therapy is significantly effective in marital adjustment of incompatible women.

\section{Method, Population and Sample}

This research is an applied study in terms of purpose and an experimental study in terms of data collection method. Also, it is a pretest-posttest quasi-experimental study design with a nonequivalent control group. The research statistical population consists of all the incompatible women who referred to the counseling clinics of Neyshabour in May 2016. The sample was chosen through available sampling method. After referring to all the clinics in Neyshabour, incompatible women who were willing to participate in the research were selected as the sample. In this way, 24 incompatible women were chosen who were randomly assigned into two experimental (12 subjects) and control (12 subjects) groups and the interventions were conducted only on the experimental group. In the present study, Spinner Marital Adjustment Scale was employed to collect the data.

\subsection{Spinner Marital Adjustment Questionnaire [21]}

This scale is a self-assessment questionnaire with 32 questions and shows the individuals' perceptions about marital adjustment. Scoring is performed based on a Likert scale. Factor analysis suggests that this scale measures four dimensions of the relationship: Dyadic satisfaction (the rate of satisfaction with various aspects of the relationship), dyadic cohesion (the rate of participation in joint activities), dyadic consensus (the amount of the two sides' agreement on issues related to marital relationship such as financial affairs, upbringing of children, etc.) and affectional expression. Scores of this questionnaire vary between zero and 151 and obtaining the scores higher than or equal to 111 indicates the adjustment of individuals and the scores lower than 111 represents the existence of a problem in marital relationships and also incompatibility and family disagreement. This scale evaluates the overall marital adjustment of the individual. Studies related to the reliability and validity of this scale have been always positive. [21] reported the overall reliability of the questionnaire to be 0.96 using Cronbach's alpha, which enjoys significant internal consistency. In the research carried out in Iran, the researchers achieved high internal consistency (0.95) in the whole questionnaire [22]. Besides, some evidence has been obtained regarding the existence of content validity by using the experts' judgment about the content of the scale. Based on the correlation of 0.86 between its results with Locke and Wallace Marital Adjustment Test, its concurrent validity has been determined [23].

\subsection{Implementation Method}

After a preliminary study and preparation of tools and referring to counseling 
and psychotherapy clinics and selection of incompatible women, the sample was randomly divided into two experimental (12 subjects) and control (12 subjects) groups. In a letter, the sample was asked to provide the necessary cooperation concerning the study and the subjects were assured that the data obtained from this study is personal and confidential and will not be made available individually to others. The inclusion criteria included the following: 1) The women should be married for more than 5 years and 2) incompatible women should not be in another treatment group and want to continue their marriage to their spouse. After implementing the interventions on the experimental group, the questionnaires were collected and the data was analyzed.

The educational content of sessions was as follows: At the beginning of each session, a summary of the discussions of the previous session was presented and report of the assignments of members was reviewed. At the end of each session, after summing up the discussions, some assignments were provided for the next session. Objectives of the training sessions are as follows (Table 1).

Table 1. Framework of the training sessions.

\begin{tabular}{|c|c|c|}
\hline Session & Overall purpose & Behavioral purpose \\
\hline 1 & $\begin{array}{l}\text { Introduction of } \\
\text { therapeutic approaches }\end{array}$ & $\begin{array}{l}\text { Introduction, explaining the group rules, introducing narrative therapy, } \\
\text { describing the dominant story of individuals in life and life narrative, } \\
\text { stating solution-focused methods and giving assignments }\end{array}$ \\
\hline 2 & $\begin{array}{l}\text { Externalization and familiarity } \\
\text { with the basic principles of } \\
\text { solution-focused counseling }\end{array}$ & $\begin{array}{l}\text { Starting externalization, examining the life narratives of individuals, my life story, } \\
\text { familiarity with the basic principles of solution-focused counseling and } \\
\text { its application, assessing the active acceptance of responsibility } \\
\text { in a relationship, formulating the rings of solutions to problems }\end{array}$ \\
\hline 3 & Attitude towards the problem & $\begin{array}{l}\text { Group discussion about the attitude towards the problem and stating the } \\
\text { individuals' solutions in this regard, participants' familiarity with helpful solutions } \\
\text { and repeating them and giving up inappropriate solutions, finding a positive story }\end{array}$ \\
\hline 4 & $\begin{array}{l}\text { Dominance and } \\
\text { rule over the individual }\end{array}$ & $\begin{array}{l}\text { Group discussion about feedback on the previous sessions, dominance and rule } \\
\text { over the committed person and encouraging the participants to solve problems, } \\
\text { identifying and solving the resistances of participants, talking about } \\
\text { future and works, using the technique of scale questions }\end{array}$ \\
\hline 5 & $\begin{array}{l}\text { Members' familiarity } \\
\text { with exceptions of the problem }\end{array}$ & $\begin{array}{l}\text { Examining one's own flaws, providing some points regarding the boosters } \\
\text { of the problem, strengthening and highlighting the exceptions of the problem, } \\
\text { making the participants realize their own potentials and capabilities, } \\
\text { role play and explaining the exercise of incomplete sentences }\end{array}$ \\
\hline 6 & $\begin{array}{l}\text { Techniques to deal with } \\
\text { negative emotions towards } \\
\text { stressful relationships of the past }\end{array}$ & $\begin{array}{l}\text { Techniques to deal with negative emotions towards stressful relationships } \\
\text { of the past and stating a narrative of individual perceptions about life events, } \\
\text { helping the participants identify other ways of thinking and admiring } \\
\text { each other instead of criticizing, implementing the technique of miracle questions }\end{array}$ \\
\hline 7 & $\begin{array}{l}\text { Rewriting the life narrative } \\
\text { from past to present }\end{array}$ & $\begin{array}{l}\text { Rewriting the life narrative from past to present, helping the participants } \\
\text { imagine their favorite future and a better world, helping the participants } \\
\text { get out of the problem framework and identify objective and desired changes }\end{array}$ \\
\hline 8 & $\begin{array}{l}\text { Summing up the sessions } \\
\text { and conclusion }\end{array}$ & $\begin{array}{l}\text { Group discussion about the changes made in individuals due to attending } \\
\text { the sessions, examining the evidence related to the change in the group, } \\
\text { summing up the sessions and conclusion, implementing the posttest, } \\
\text { thanks and appreciation to the members for their participation in the session }\end{array}$ \\
\hline
\end{tabular}




\subsection{Data Analysis Method}

The data obtained from the scores of this study is analyzed at two descriptive and inferential levels. At the descriptive level, indicators such as mean, standard deviation, frequency and percentage were used and at the inferential level, covariance analysis by SPSS-22 statistical software was applied.

\section{Findings}

To describe the data relating to the sample, central indices and dispersion of the research variables were initially calculated, which is as follows.

As can be observed in Table 2, the average score of marital adjustment (dyadic satisfaction, dyadic cohesion, dyadic consensus and affectional expression) of the subjects in the experimental group has had a significant increase in the posttest stage compared to the pretest, but this change is not observed in the control group.

In this study, multivariate analysis of covariance test has been employed due to more appropriateness and compatibility with the research hypotheses. Before conducting the analysis of covariance test, three assumptions (normal distribution of scores, homogeneity of variances and consistency of covariance matrices) were investigated, whose results have been provided in the tables below (Tables 3-5).

Results of Kolmogorov-Smirnov test have been presented in Table 3. Distribution of scores in all components is normal since the significance level of Kol-

Table 2. Descriptive indicators between the experimental $(\mathrm{N}=12)$ and control $(\mathrm{N}=12)$ groups in the variable of marital adjustment.

\begin{tabular}{|c|c|c|c|c|c|c|c|}
\hline & Variable & Group & Type & Mean & Adjusted mean & $\mathrm{SD}$ & Adjusted SD \\
\hline \multirow{16}{*}{ Marital adjustment } & \multirow{4}{*}{ Dyadic satisfaction } & \multirow{2}{*}{ Experimental } & Pretest & 29.00 & 41.26 & 3.04 & 1.42 \\
\hline & & & Posttest & 40.42 & & 6.24 & \\
\hline & & \multirow{2}{*}{ Control } & Pretest & 32.92 & 33.15 & 4.01 & 1.42 \\
\hline & & & Posttest & 34.08 & & 4.83 & \\
\hline & \multirow{4}{*}{ Dyadic cohesion } & \multirow{2}{*}{ Experimental } & Pretest & 10.92 & 17.62 & 2.23 & 0.92 \\
\hline & & & Posttest & 17.83 & & 4.26 & \\
\hline & & \multirow{2}{*}{ Control } & Pretest & 13.25 & 13.87 & 2.66 & 0.92 \\
\hline & & & Posttest & 13.67 & & 2.06 & \\
\hline & \multirow{4}{*}{ Dyadic consensus } & \multirow{2}{*}{ Experimental } & Pretest & 13.92 & 50.45 & 8.36 & 1.85 \\
\hline & & & Posttest & 48.50 & & 5.50 & \\
\hline & & \multirow{2}{*}{ Control } & Pretest & 40.58 & 41.30 & 6.17 & 1.85 \\
\hline & & & Posttest & 41.50 & & 4.89 & \\
\hline & \multirow{4}{*}{ Affectional expression } & \multirow{2}{*}{ Experimental } & Pretest & 8.75 & 13.93 & 2.63 & 0.71 \\
\hline & & & Posttest & 13.33 & & 2.57 & \\
\hline & & \multirow{2}{*}{ Control } & Pretest & 10.00 & 10.72 & 1.80 & 0.71 \\
\hline & & & Posttest & 10.67 & & 1.49 & \\
\hline
\end{tabular}


Table 3. Results of examining the normality of the distribution of marital adjustment scores.

\begin{tabular}{ccccc}
\hline Variable & Dimensions of the variable & Test & Z value & Significance level \\
\hline & Dyadic satisfaction & Pretest & 0.81 & 0.52 \\
& & Posttest & 0.73 & 0.66 \\
& Dyadic cohesion & Pretest & 0.77 & 0.58 \\
Marital & & Posttest & 0.84 & 0.46 \\
adjustment & Dyadic consensus & Pretest & 1.18 & 0.11 \\
& & Posttest & 0.72 & 0.66 \\
& Affectional expression & Pretest & 0.70 & 0.70 \\
& & Posttest & 0.89 & 0.36 \\
\hline
\end{tabular}

Table 4. Continue from Table 3.

\begin{tabular}{cccccc}
\hline Variable & $\begin{array}{c}\text { Dimensions of } \\
\text { the variable }\end{array}$ & Levene & $\begin{array}{c}\text { Degree of } \\
\text { freedom 1 }\end{array}$ & $\begin{array}{r}\text { Degree of } \\
\text { freedom 2 }\end{array}$ & $\begin{array}{c}\text { Significance } \\
\text { level }\end{array}$ \\
\hline \multirow{3}{*}{$\begin{array}{c}\text { Marital } \\
\text { adjustment }\end{array}$} & Dyadic satisfaction & 1.80 & 1 & 22 & 0.19 \\
& Dyadic cohesion & 4.13 & 1 & 22 & 0.05 \\
& Dyadic consensus & 0.67 & 1 & 22 & 0.41 \\
& Affectional expression & 1.83 & 1 & 22 & 0.83 \\
\hline
\end{tabular}

Table 5. Box test to ensure the homogeneity of covariance matrix of marital adjustment.

\begin{tabular}{ccccc}
\hline Indicators & $F$ & Degree of freedom 1 & Degree of freedom 2 & Significance level \\
\hline Values & 1.81 & 10 & 2313.94 & 0.05 \\
\hline
\end{tabular}

mogorov-Smirnov test has been obtained to be higher than 0.05 for all components. So, the first assumption has been observed. The results provided in Table 4 demonstrate that the assumption of the homogeneity of variances has been observed in all components. As can be seen, the results shown in Table 5 indicate that the Box test is not significant $(P=0.053, \mathrm{~F}=1.817)$. In other words, covariance matrices are homogeneous. Thus, the third assumption has been also observed. With regard to the significance of the test assumptions, analysis of covariance test is used.

To evaluate the research hypothesis indicating the effectiveness of the combination of solution-focused therapy and narrative therapy in marital adjustment among incompatible women, analysis of covariance method was applied, whose results are as follows (Table 6).

Table 6 shows the results obtained from the covariance test in marital adjustment score. The results reveal that in the components of marital adjustment, the difference between the groups is statistically significant $(P<0.001)$. Hence, the existence of difference between the experimental and control groups can be accepted. Additionally, the effect size of the intervention is $51 \%$ for dyadic satisfaction, $42 \%$ for dyadic cohesion, $45 \%$ for dyadic consensus and $35 \%$ for affect- 
Table 6. Results of covariance analysis regarding the difference between the experimental and control groups in terms of the average score of marital adjustment.

\begin{tabular}{ccccccc}
\hline $\begin{array}{c}\text { Covariate } \\
\text { variables }\end{array}$ & Dependent variables & $\begin{array}{c}\text { Degree } \\
\text { of freedom }\end{array}$ & $\begin{array}{c}\text { Mean } \\
\text { Square }\end{array}$ & F value & $\begin{array}{c}\text { Significance } \\
\text { level }\end{array}$ & $\begin{array}{c}\text { Effect } \\
\text { size }\end{array}$ \\
\hline \multirow{2}{*}{$\begin{array}{c}\text { Group } \\
\text { membership }\end{array}$} & Dyadic satisfaction & 1 & 456.17 & 22.07 & $0.001\left({ }^{* *}\right)$ & 0.51 \\
& Dyadic cohesion & 1 & 154.50 & 15.04 & $0.001\left({ }^{* *}\right)$ & 0.42 \\
& Dyadic consensus & 1 & 401.26 & 17.24 & $0.001\left({ }^{* *}\right)$ & 0.45 \\
& Affectional expression & 1 & 48.39 & 11.13 & $0.003\left({ }^{* *}\right)$ & 0.35 \\
\hline
\end{tabular}

${ }^{* *}$ Significance at the level of 0.01 .

tional expression. In other words, the subjects of the experimental group have had $35 \%$ to $51 \%$ increase in marital adjustment (dyadic satisfaction, dyadic cohesion, dyadic consensus and affectional expression) relative to the control group. Thus, the research hypothesis stating that the combination of solutionfocused therapy and narrative therapy is effective in the subscales of marital adjustment among incompatible women was confirmed. It should be noted that with regard to Table 2, the adjusted mean score of the subscales of marital adjustment in the experimental group is greater than the control group.

\section{Discussion and Conclusion}

The aim of the present study is to investigate the effectiveness of the combination of solution-focused therapy and narrative therapy in marital adjustment of incompatible women. The overall research results suggested that the combination of solution-focused therapy and narrative therapy is effective in marital adjustment of incompatible women and there is significant difference between the experimental and control groups in the component of marital adjustment so that the scores of marital adjustment in the experimental group compared to the control group showed a significant increase in the posttest stage.

The results of the studies by [21]-[27] are consistent with the findings of this research and show the effectiveness of the combination of solution-focused therapy and narrative therapy in marital adjustment of incompatible women. In explaining the results of this study, it can be stated that [14] developed the narrative therapy model, following the theory of dialogue based on the stories. The purpose of these interventions is to help the clients externalize a cumbersome and difficult problem. In this approach, the client and therapist are indeed the editors of the client's personal biography and the therapy is the editing of the personal biography. Therefore, this method provides an active role for the client in the treatment. In this approach, the individual learns to assume his responsibility in relieving and improving his own psychological problems. When writing the life story, the individual thinks about it at the same time, selects some parts of it and puts aside unimportant parts. In fact, he becomes the editor of his own story and this is what is emphasized in this approach. This approach views people as the specialists of their own life and considers problems as the separate sections from people and believes that individuals possess many skills, beliefs, 
values and abilities that help them in reducing the effects of problems on their lives. Thus, the process of narrative therapy is a highway to heal the events of the past and pass them and is a smooth road which drives the individuals towards a future with positive meaning. The result of such an attitude will be inner peace. After finding the inner peace, the solution-focused approach gives the clients the opportunity to review and reconsider the methods they had considered for resolving the conflicts and also the roles they had determined for themselves and others in the path to adjustment such that after the awareness of having a choice between conflict resolution and escalation of conflicts, they engage in the correct handling of their marital conflict and incompatibility. Considering what has been mentioned so far, the combination of solution-focused therapy and narrative therapy leads to enhanced marital adjustment among incompatible women.

Furthermore, in explaining the results of the present study suggesting the effectiveness of the combination of solution-focused therapy and narrative therapy in the subscales of marital adjustment (dyadic satisfaction, dyadic cohesion, dyadic consensus and affectional expression), it can be said that in the solution-focused approach, the therapist lays the emphasis on the fact that language determines meaning. Rather than relying on external analysis and search for truth by an expert, a dialogue should begin between the therapist and client. The underlying philosophy of the solution-focused model is that continuous changes are inevitable and in this treatment, what is possible and variable is emphasized not what is impossible. According to [12], it can be stated that solution-focused therapists more than the therapists of the Mental Research Institute (MRI) ensure the clients that they reach their specific goals. In their opinion, people already have the skills to solve their problems; but these problems are so great in their views that they forget their strengths and ignore their abilities. Sometimes, a simple change in the focus of attention from what does not seem good to what they already do and is effective can make the clients remember their capabilities and widely use these resources. Consequently, with the application of the solution-focused approach, we could induce this belief to them that their satisfaction depends on their effort to gain satisfaction and by considering the strength within oneself, reaching satisfaction is not impossible. As a result, with the help of the solution-focused approach and by highlighting the strong points of the clients' married life in the form of narrative expression provided by them, we attempted to improve their motivation to achieve marital adjustment. Based on the foregoing, it can be said that the combination of solution-focused therapy and narrative therapy is effective in the subscales of marital adjustment.

But this study was faced with specific limitations including the inattention of some subjects and also their dishonesty in answering the questionnaire. Their low motivation and lack of interest caused them not to cooperate properly, especially given that therapeutic interventions need more time to be effective. Considering the results of this research, it is recommended that the therapists widely use the results of this study to conduct training workshops in connection with solution-focused sessions, narrative therapy and rewriting the life story in 
schools, universities, companies and different institutions and benefit from various dimensions of these treatment methods to create marital adjustment and happy lives without conflict for couples.

\section{References}

[1] Ameri, F., Nourbala, A., Ezheei, J. and Rasoulzadeh Tabatabaei, K. (2003) Examining the Influence of the Interventions of Strategic Family Therapy on Marital Disputes. Journal of Psychology, 7, 218-232.

[2] Ball, J., Mitchell, P., Malhi, G., Skillecorem, A. and Smith, M. (2011) Co-Constructing a Marriage: Analyses of Young Couples' Relationship Narratives. Monographs of the Society for Research in Child Development, 12, 37-51.

[3] Bannink, F.P. (2007) Solution-Focused Brief Therapy. Journal of Contemporary Psychotherapy, 3, 87-94. https://doi.org/10.1007/s10879-006-9040-y

[4] Bradshaw, J. (2010) Family (Family Systems Analysis). Translated by M. QaracheDaghi, Alborz, Tehran. (The Publication Date of the Work in the Original Language, 2010)

[5] Brzezowskl, K.M. (2012) A Solution-Focused Grouped Treatment Approach for Individuals Maladaptively Expressing Anger. Wright State University, Dayton, $\mathrm{OH}$.

[6] Cornelius, F., Tara, G., Alessi, D. and Galen, B.V. (2007) Behavioral and Physiological of Communication Training: Does the Topic Affect Outcome? Journal of Marriage and Family, 69, 608-620. https://doi.org/10.1111/j.1741-3737.2007.00395.x

[7] Amini Soulari, F. (2010) Effectiveness of Narrative Couples Therapy in Marital Satisfaction of Couples in Isfahan. MA Thesis, University of Isfahan, Isfahan.

[8] Dastbaz, A. (2013) Comparing the Effectiveness of "Solution-Focused" Group Counseling and Narrative Therapy in Adjustment and Self-Efficacy of First Grade Secondary School Students. MA Thesis, University of Welfare and Rehabilitation Sciences, Tehran.

[9] De Jong, P. and Berg, I.K. (2012) Interviewing for Solutions. 4nd Edition, Brooks Cole, Pacific Grove, CA, 152.

[10] Eskandarpour, N. (2014) Investigating the Impact of Narrative Therapy Training on Reduced Marital Dissatisfaction in the Couples of Tehran. 1st International Conference on Psychology and Behavioral Sciences.

[11] Fisher, T.D. and McNulty, J.K. (2008) Neuroticism and Marital Satisfaction: The Mediating Role Played by the Sexual Relationship. Journal Family Psychology, 22, 112-122. https://doi.org/10.1037/0893-3200.22.1.112

[12] Frost, D.M. (2013) The Narrative Construction of Intimacy and Affect in Relationship Stories: Implications for Relationship Quality, Stability, and Mental Health. Journal of Social and Personal Relationships, 30, 247-269. https://doi.org/10.1177/0265407512454463

[13] Gong, M. (2007) Does Status in Consistency Matter for Marital Quality? Journal of Family Issues, 28, 152-161.

[14] Spanier, G.B. (1976) Measuring Dyadic Adjustment: New Scales for Assessing the Quality of Marriage and Similar Dyads. Journal of Marriage and the Family, 38, 1528. https://doi.org/10.2307/350547

[15] Zeidner, M. and Kloda, I. (2013) Emotional Intelligence (EI), Conflict Resolution Patterns, and Relationship Satisfaction: Actor and Partner Effects Revisited. Personality and Individual Differences, 54, 278-283.

https://doi.org/10.1016/j.paid.2012.09.013 
[16] Morse, J.M. (2012) Introducing the First Global Congress for Qualitative Health Research: What Are We? What Will We Do- and Why? Qualitative Health Research, 22, 147-156.

[17] Mollazadeh, J., Mansour, M., Ezheei, J. and Kiyamanesh, A.R. (2002) Coping Styles and Marital Adjustment in Shahed Children. Journal of Psychology, 6, 255-275.

[18] Wand, T. (2010) Mental Health Nursing from a Solution Focused Perspective. International Journal of Mental Health Nursing, 19, 210-219. https://doi.org/10.1111/j.1447-0349.2009.00659.x

[19] Weisi, A. (2012) Designing and Comparing the Effectiveness of the Treatment Program Based on the Principles of Narrative Therapy and Treatment Based on Quranic Teachings in Reducing Marital Conflicts. Journal of Counseling and Family Psychotherapy, 2, 341-357.

[20] White, M. and Epston, D. (1990) Narrative Means to Therapeutic Ends. W. W. Norton, New York.

[21] Busby, D.M., Christensen, C., Crane, D.R. and Larson, J.H. (1995) A Revision of the Dyadic Adjustment Scale for Use with Distressed and Nondistressed Couples: Construct Hierarchy and Multidimensional Scales. Journal of Marital and Family Therapy, 21, 289-308. https://doi.org/10.1111/j.1752-0606.1995.tb00163.x

[22] Narimani, M., Abbasi, M., Bagian Kouleh Marz, M.J. and Bakhti, M. (2014) Comparing the Effectiveness of the Training Approach Based on Acceptance and Commitment and Group Narrative Therapy in Modifying Early Maladaptive Schemas of the Clients Seeking Divorce. Journal of Counseling and Family Psychotherapy, 4, $1-28$.

[23] Polkinghrone, D.E. (2010) Narrative and Postmodernism. In: Angus, L.E. and McLeod, J., Eds., The Handbook of Narrative and Psychotherapy, SAGE Publication, London, 53-103.

[24] Sehhat, F., Sehhat, N., Khanjani, S., Mohebbi, S. and Shah Siyah, M. (2014) The Effect of Short-Term Solution-Focused Approach on Reducing Marital Conflicts in Qom. Journal of Health System Research, 10, 268-275.

[25] Shakarami, M., Davarniya, R. and Zahrakar, K. (2015) Effectiveness of Short-Term Solution-Focused Therapy in Reducing the Marital Stress of Women. Journal of Medical Sciences University of Ilam, 22, 18-26.

[26] Qorbanalipour, M., Farahani, H., Borjali, A. and Moqaddas, L. (2008) Determining the Effectiveness of Training Group Lifestyle Change in Increased Marital Satisfaction. Journal of Psychological Studies, 4, 57-72.

[27] Priscilla, W.B. and Vandergriff-Avery, M. (2001) Marital Therapy and Marital Power: Constructing Narratives of Sharing Relational and Positional Power. Contemporary Family Therapy, 23, 259-308. 
Submit or recommend next manuscript to SCIRP and we will provide best service for you:

Accepting pre-submission inquiries through Email, Facebook, LinkedIn, Twitter, etc. A wide selection of journals (inclusive of 9 subjects, more than 200 journals)

Providing 24-hour high-quality service

User-friendly online submission system

Fair and swift peer-review system

Efficient typesetting and proofreading procedure

Display of the result of downloads and visits, as well as the number of cited articles Maximum dissemination of your research work

Submit your manuscript at: http://papersubmission.scirp.org/

Or contact ojpsych@scirp.org 